\title{
SPIRIT RELIGI MASYARAKAT DESA TAMBAK ANYAR ULU DALAM MENINGKATKAN PARTISIPASI DI BIDANG PENDIDIKAN MADRASAH SWASTA
}

\author{
RABINI SAYYIDATI \\ Dosen MKDU di Politeknik Negeri Tanah Laut \\ Jl. A. Yani Km. 6 Ds. Panggung Kec. Pelaihari Kab. Tanah Laut, Kalimantan Selatan \\ email: rabini.sayyidati@gmail.com
}

\begin{abstract}
The strong phenomenon in religious spirit of Tambak Anyar Ulu people in participating for the education in private Islamic Madrasah self-dependently without any foundation to help them and without expecting government assistance are somewhat has become something unique. The research method used was qualitative method that was used to portray the cultural phenomenon in a rural community, particularly the participation of people in Tambak Anyar Ulu in the field of private Madrasah. The findings of this study are: 1) The forms of religious spirit activities of people of Tambak Anyar Ulu in an effort to increase their participation in the field of private madrasah education. 2) Religious spirit of teachers and learners in Madrasah Auladil Tarbiyyatul Islam's education. 3) Madrasah Tarbiyyatul Auladil Islam is a pure private madrasah. 4) The people of Tambak Anyar Ulu were motivated to participate in Islamic education in private madrasah of Tarbiyyatul Auladil Islam compared to their participation in state public schools. In conclusion, the result of this research shows that the people of Tambak Anyar Ulu have been proven to be actively participating for the education in private Islamic Madrasah with the religious spirit as its baseline.
\end{abstract}

Keywords: Spirit of religion, Partisipation, Education, Private Madrasah

\begin{abstract}
Abstrak
Fenomena kuatnya spirit religi masyarakat Tambak Anyar Ulu dalam berpartisipasi di bidang pendidikan madrasah Islam swasta dengan swadaya murni tanpa yayasan dan tanpa mengharapkan bantuan pemerintah menjadi keunikan tersendiri. Metode penelitian yang dipakai adalah metode kualitatif yang mampu menggambarkan fenomena budaya suatu masyarakat pedesaan, khususnya partisipasi masyarakat Tambak Anyar Ulu di bidang madrasah swasta. Hasil penelitian berupa 1) Bentuk-bentuk aktivitas spirit religi masyarakat Tambak Anyar Ulu dalam upaya meningkatkan partisipasi dibidang pendidikan madrasah swasta. 2) Spirit religi para guru dan peserta didik dalam pendidikan Madrasah Tarbiyatul Auladil Islam. 3) Madrasah Tarbiyyatul Auladil Islam adalah madrasah swasta murni. 4) Masyarakat Tambak Anyar Ulu tergerak dalam partisipasi pendidikan Islam pada Madrasah Swasta Tarbiyyatul Auladil Islam dibandingkan dengan partisipasi pada sekolah umum negeri.
\end{abstract}


Kesimpulan penelitian yaitu masyarakat Tambak Anyar Ulu berperan aktif dalam partisipasinya di bidang pendidikan madrasah Islam swasta dengan spirit religi sebagai landasan dasarnya.

Kata kunci : Spirit Religi, Partisipasi, Pendidikan, Madrasah Swasta

\section{PENDAHULUAN}

Diantara sekian banyak lembaga pendidikan di Indonesia yang berupaya membangun manusia Indonesia seutuhnya antara lain adalah lembaga pendidikan madrasah Islam swasta. Pemerintah Republik Indonesia telah menuangkan eksistensi madrasah Islam dalam Peraturan Pemerintah (PP) N0.55 tahun 2007 tentang Pendidikan Agama dan Keagamaan. Secara eksplisit PP ini mengatur madrasah yang memfokuskan pada pendidikan keagamaan Islam.

Secara kenyataan, pendidikan madrasah swasta memang bertebaran di Kalimantan Selatan, khususnya di kecamatan Martapura Kabupaten Banjar. Pendidikan madrasah Islam swasta sebelum tahun 1975 telah ada pada setiap desa di berbagai lingkungan kampung di Martapura Kabupaten Banjar.

Menurut Yusliani Noor (2012:14) Martapura Kabupaten Banjar dikenal sebagai serambi Mekkah yang dalam sejarahnya memiliki ulama besar dalam kancah internasional, nasional, regional, dan lokal menjadi faktor penting dalam menumbuhkembangkan partisipasi masyarakat dalam membangun madrasah Islam.

Satu kampung diantara kampung yang lainnya dalam kawasan kecamatan Martapura, Kabupaten Banjar yang memiliki minat dan partisipasi yang kuat pada pendidikan madrasah Islam adalah Kampung Tambak Anyar Ulu yang telah memiliki pendidikan madrasah Islam sejak tahun 1956. Pada mulanya madrasah yang bernama Tarbiyyatul Auladil Islam berdiri di tanah seluas dua borongan (satu borongan ukuran $17 \mathrm{mx} 17 \mathrm{~m}$ ) dengan bangunan sederhana seluas $17 \mathrm{mx} 17 \mathrm{~m}$. Kemudian sampai sekarang, tahun 2014, telah memiliki dua lokasi, yakni satu lokasi untuk tingkat Ibtidaiyyah (enam tahun), dan tingkat Tsanawiyyah (tiga tahun).

Partisipasi masyarakat dalam membangun madrasah, tidak terlepas dari emosi keagamaan yang melahirkan semangat keagamaan (spirit religi). Menurut Koentjaraningrat (1986:376) semua aktivitas manusia yang bersangkutan dengan religi berdasarkan atas getaran jiwa yang biasa disebut emosi keagamaan (religious emotion). Emosi keagamaan yang menyangkut motivasi dan semangat partisipasi dalam kerangka membangun madrasah Islam dapat diistilahkan sebagai spirit religi. Istilah spirit religi dapat diartikan sebagai spirit agama 
(Muhaimin, 2006:104). Spirit agama dalam versi Weber adalah adanya hubungan yang kuat antara etika protestan dengan semangat kapitalisme. Ajaran agama ada hubungannya dengan ekonomi (Abdullah, 1979:4). Agama mendorong munculnya sejumlah tokoh istimewa dalam jumlah banyak dan kebetulan mereka menciptakan sebuah ekonomi baru (sebuah mode produksi baru) yang kita kenal sebagai kapitalisme (Harrison \& Huntington, 2006:42). Max Weber membuat tesis yang menekankan kuatnya spirit religi atau semangat agama dalam masyarakat protestan, sehingga mendorong terciptnya kemajuan dan kemakmuran masyarakat, khususnya di Eropa bagian Utara dalam abad ke-16 hingga 18. Agama, mendorong pembentukan karakter manusia yang rasional, tertib, rajin, dan produktif. Nilai-nilai ini menjadi spirit yang menjadi standar-standar ketaatan dalam perilaku. Menurut pengertian lainnya, spirit agama memiliki pengaruh yang kuat dalam konteks kesehatan jiwa.

Pendidikan umum yang zaman dulu di kampung Tambak Anyar Ulu disebut sekolah Walanda (Belanda), pada mulanya hanya terdapat dua sekolah, yakni SDN Setia Budi Tambak Anyar dan SDN Sungai Liang Subarangbanyu. Setelah tahun 1979, terjadi pemekaran Kampung Tambak Anyar, maka di Kampung Tambak Anyar Ulu yang sebelumnya telah berdiri Sekolah SDN Inpres tahun 1976 yang tanahnya berasal dari wakaf masyarakat setempat. Namun SDN ini selalu dibangun dengan biaya pemerintah dengan guru-guru yang juga digaji pemerintah sebagai PNS (pegawai negeri sipil). SDN ini sampai tahun 2010, tiap tahunnya hanya meluluskan kurang dari 15 orang karena para siswanya banyak berhenti dan lebih memilih untuk belajar di madrasah (data angka kelulusan SDN Tambak Anyar Ulu dari 1979-2010). Bahkan terkadang kurang dari 10 orang.

Berbeda halnya dengan madrasah, peminatnya selalu penuh dengan jumlah lulusan lebih dari 15 orang tiap tahunnya (lihat data kelulusan Madrasah Tarbiyyatul Auladil Islam, Tambak Anyar Ulu, 1979-2010). Hal ini menandakan adanya spirit religi yang ada pada ustaz (guru) dan peserta didik yang lebih berminat kepada madrasah dari pada sekolah umum.

Berdasarkan kenyataan demikian maka terselenggaranya pendidikan madrasah Islam di Tambak Anyar Ulu, bersumber dari partisipasi masyarakat dan sepenuhnya berasal dari dana yang dikumpulkan dalam berbagai acara amal pada setiap kegiatan peringatan hari besar Islam. Kesadaran dan kerelaan berkorban masyarakat setempat dalam membantu sepenuhnya biaya pendidikan madrasah Islam pada setiap kegiatan yang diselenggarakan panitia penyelenggara menjadi fenomena spirit religiusitas. 
Fenomena kuatnya spirit religi masyarakat Tambak Anyar Ulu dalam berpartisipasi membangun dan menyelenggarakan pendidikan madrasah Islam dengan swadaya murni, semangat gotong royong dan keikhlasan para guru serta peserta didik dalam proses belajar mengajar, tanpa yayasan dan tanpa mengharapkan bantuan pemerintah menjadi keunikan tersendiri. Hal ini bertentangan dengan fenomena pendidikan umum dan pendidikan sekolah agama negeri yang sangat bergantung pada pemerintah pusat dan daerah yang semua dananya sampai guru-gurunya menjadi guru PNS (pegawai negeri sipil). Kebanyakan orang dewasa ini hanya berfokus kepada materi serta kurangnya spirit religi di bidang pendidikan.

\section{METODE PENELITIAN}

Penelitian ini merupakan kajian sosial-budaya tentang spirit religi masyarakat Tambak Anyar Ulu dalam partisipasi di bidang pendidikan madrasah Islam swasta yang tentu saja menggunakan pendekatan sosial. Fenomena-fenomena bentuk aktivitas spirit religi dan partisipasi dalam bidang pendidikan diperlukan telaah khusus dan mendalam yang tidak bisa dilepaskan dari budaya yang menjadi latar dari suatu aktivitas masyarakat dan berbagai peristiwa sosial.

Penelitian kualitatif menurut Agus Salim (2001:8), sebagai perangkat interpretatif terhadap fenomena sosial. Oleh sebab itu, penelitian ini menggunakan model kualitatif. Melalui pendekatan kualitatif peneliti mengeksplor fenomena-fenomena yang tak bisa dikuantitaskan sebab sifatnya melihat gejala suatu budaya (Wahyu, 2012:3). Sementara menurut Nusa Putra (2013:45), bahwa penelitian kualitatif didasarkan pada paradigma fenomenologi peneliti untuk sampai pada emik (sudut pandang/perspektif/perasaan) orang atau komunitas.

Metode kualitatif membantu untuk melihat dan menggambarkan tindakan dan cara-cara mengumpulkan data yang dianalisis dengan pendekatan sosial yang tercermin pada spirit religi dalam ajaran Islam yang dikenal sebagai etika Islam. Melalui metode kualitatif fenomena perilaku tradisi dalam suatu budaya tergambar secara detail, lebih jernih dan mampu menggambarkan fenomena budaya suatu masyarakat pedesaan, khususnya partisipasi masyarakat dibidang pendidikan madrasah Islam swasta pada kampung Tambak Anyar Ulu. 


\section{HASIL DAN PEMBAHASAN}

\section{Bentuk Spirit Religi Masyarakat Tambak Anyar Ulu dalam Upaya Meningkatkan Partisipasi Bidang Pendidikan Madrasah Swasta}

Spirit religi adalah semangat berdasarkan kepercayaan. Dalam konteks Islam, konsep religi adalah ad-dien atau agama. Oleh sebab itu, spirit religi adalah semangat berdasarkan agama, yakni agama Islam. Semua aktivitas manusia yang bersangkutan dengan religi berdasarkan atas getaran jiwa yang biasanya disebut emosi keagamaan (Koentjaraningrat ,1986:376).

Kesadaran membangun madrasah diwujudkan dalam bentuk partisipasi secara penuh dari seluruh lapisan masyarakat Tambak Anyar Ulu untuk membangun dan menyelenggarakan pendidikan Islam sehingga sekarang madrasah swasta itu telah berusia sekitar 58 tahun.

Religiusitas Islam yang menjadi fenomena sosial budaya masyarakat Tambak Anyar Ulu yang kebetulan 99\% etnis Melayu Banjar, sisanya adalah etnis Jawa, namun semuanya beragama Islam. Kenyataan ini menumbuhkan kesadaran agama, yakni spirit religi atau semangat keagamaan yang sangat kuat dalam partisipasi masyarakat pada bidang pendidikan agama Islam, yakni madrasah swasta.

Partisipasi di bidang pendidikan Islam, yakni madrasah swasta pada masyarakat Tambak Anyar Ulu karena secara faktual telah disokong oleh masyarakat yang religius. Masyarakat yang religius Islam melahirkan semangat Islam untuk meningkatkan pendidikan Islam bagi anak-anak desa setempat.

Semangat Islam merupakan spirit religi yang dilandasi nilai keimanan dan keyakinan kepada Allah Swt. Spirit religi tidak mungkin lahir begitu saja tanpa adanya landasan sakral dari masyarakat religius yang Islami. Masyarakat yang Islami memiliki tradisi Islam yang kuat untuk membangun madrasah. Hal inilah yang disebutkan oleh Muhaimin (2006:104), bahwa madrasah berkembang dari, oleh dan untuk masyarakat muslim itu sendiri. Karena itu, Durkheim dalam konsep umumnya yang lebih mengupas religi masyarakat kuno, memandang bahwa religi adalah sumber kekuatan moral. Kekuatan moral adalah upaya harmoni untuk menciptakan dan mempertahankan hegemoni masyarakat religius yang telah mentradisi. Upaya mempertahankan masyarakat agamis yang religius Islami dalam masyarakat Tambak Anyar Ulu merupakan hal yang alamiah, sesuai dengan spirit religi yang juga berproses secara alami. 
Spirit Religi yang Islami itu, berbentuk kegiatan saprah amal, yakni akumulasi kegiatan amal seluruh lapisan masyarakat dengan segala macam jenisnya. Mulai dari warung amal, derma langsung (infaq), pembagian amplop sumbangan, wakaf langsung, yang semuanya dilaksanakan secara gotong royong (gawi sabumi, kayuh baimbai). Bentuk aktivitas tersebut menghimpun dana masyarakat secara massif. Masyarakat tergerak menyumbangkan pikiran, tenaga dan keuangan dengan tujuan sama, kepentingan yang sama, yakni berpartisipasi dalam pembangunan serta penyelengaraan pendidikan madrasah swasta, Tarbiyyatul Auladil Islam Tambak Anyar Ulu. Bentuk spirit religi lainnya adalah memberikan zakat mal (harta) setiap tahun sekali, dan zakat firah menjelang hari raya Idul fitri.

Bentuk spirit religi tersebut, dilandasi niat yang ikhlas, sebagai bentuk pengamalan ajaran agama Islam semata-mata karena Allah Swt. Spirit religi ini, menjadi bukti perpaduan adanya kesalehan individu dan kesalehan sosial dalam kehidupan masyarakat Tambak Anyar Ulu yang religius Islami. Ternyata, kekuatan partisipasi ini, bersinergi dengan spirit ekonomi perdagangan masyarakat, yang menjadikan wirausaha sebagai bagian penting dari kehidupan masyarakat Tambak Anyar Ulu. Hasil wirausaha itu, sebagian besar diniatkan untuk beramal pada madrasah Tarbiyyatul Auladil Islam. Kekuatan wirausaha itu sendiri terinspirasi dari pola tradisi madrasah yang menekankan kemandirian dalam berusaha.

\section{Spirit Religi Para Guru (Ustaz) dan Peserta Didik Madrasah Tarbiyyatul Auladil Islam}

\section{Tambak Anyar Ulu}

Buku Tradisi Pesantren dari Zamakhsyari Dofier (2011:92-93) menjelaskan tentang konsep Kyai di Jawa sebagai pengasuh pondok pesantren dan sekaligus pengajar. Pada masyarakat Banjar di Kalimantan Selatan, istilah yang paling lazim adalah Tuan Guru. Kata guru merupakan kata yang menjadi awal dalam penyebutan status seorang Ulama.

Masyarakat Banjar sangat jarang menyebut istilah ustaz yang berasal dari kata bahasa Arab, yang artinya guru. Oleh sebab itu, ulama yang paling alim tetap disebut guru. Paguruan atau guru dalam bidang apa saja, selalu dihormati. Namun untuk guru Madrasah Tarbiyyatul Auladil Islam, masyarakat Tambak Anyar Ulu bukan sekedar menghormati tetapi juga memuliakan. Menghormati merupakan sikap yang didasari adanya adab sopan santun dalam tata pergaulan di desa, sedangkan memuliakan adalah meninggikan posisi dan derajat guru dibandingkan dengan masyarakat lainnya. 
Seorang guru madrasah dalam masyarakat Tambak Anyar Ulu memiliki tanggungjawab yang berat karena harus mampu memaksimalkan antara ilmu dan amal perbuatan. Oleh sebab itu, seorang guru madrasah dalam konteks pengabdiannya sebagai guru madrasah memiliki spirit religi yang berlandaskan Al-Qur'an dan As-sunnah (Al-Hadist) dan pandangan ulama muslim.

Etika Islam hanya membumi jika diajarkan secara langsung di madrasah diniyyah yang merepresentasikan kultur pendidikan Islam di Indonesia, termasuk di desa Tambak Anyar Ulu. Oleh sebab itu, patron etika Islam di madrasah adalah guru-guru madrasah yang memiliki ijazah untuk mengajarkan kitab-kitab kuning bagi murid-muridnya atau peserta didiknya.

Hasil penyalinan kepribadian (tabarruk) menghasilkan guru madrasah yang memiliki sifat terpuji untuk mengemban tugas sebagai guru.

Peserta didik dalam sebutan yang lazim untuk siswa Madrasah Tarbiyyatul Auladil Islam disebut murid. Istilah murid berasal dari bahasa Arab yang artinya orang yang menyerahkan hatinya dengan penuh ridha untuk dibimbing oleh gurunya. Secara sederhana dapat disebut dengan peserta didik.

Menurut Sudarwan Danim (2010:67), sebagai manusia yang tumbuh dewasa, peserta didik meningkatkan pengembangan dalam kognisi sosial atau pengetahuan, pengalaman, dan pemahaman tentang kehidupan masyarakat dan aturan-aturan perilaku sosial.

Peserta didik Madrasah Tarbiyyatul Auladil Islam Tambak Anyar Ulu berasal dari anak-anak warga desa tersebut. Mereka terpanggil secara sosio-kultural untuk sekolah madrasah di desa itu, ketika sudah berusia enam tahun. Pada usia itu, mereka telah menyelesaikan pendidikan TK Al-Qur'an. Mereka telah mengenal huruf-huruf hijaiyyah, yakni huruf Arab. Mereka masuk di kelas satu awaliyah atau ibtidaiyyah. Mereka juga menyesuaikan perilakunya dengan perilaku masyarakat setempat, melalui pendidikan dari orang tuanya, di rumah dan lingkungan pendidikan TK Al-Qur'an yang diajarkan para gurunya.

Seorang peserta didik di desa Tambak Anyar Ulu selalu bersekolah di madrasah sebagai tujuan utama. Kemudian, mereka mendaftar di SDN Berkat Sadar yang juga letaknya di desa itu. Madrasah Tarbiyyatul Auladil Islam adalah keharusan bagi seorang anak, mengingat kultur masyarakat Tambak Anyar Ulu lebih mengedepankan pendidikan madrasah bagi anak-anaknya. Artinya, sekolah di Madrasah Tarbiyyatul Auladil Islam bukan suatu pilihan. Lebih baik sekolah madrasah daripada di SDN. 
Kenyataan di atas bersumber dari spirit religi yang telah tumbuh dalam masyarakat Tambak Anyar Ulu yang religius Islami. Implikasinya, meningkatkan spirit religi peserta didik untuk bersekolah di Madrasah Tarbiyyatul Auladil Islam di desa itu, sekaligus menumbuhkan sense of belonging terhadap madrasah di desanya. Partisipasi para peserta didik secara kultural menjadikan madrasah sebagai salah satu icon pendidikan di desa mereka.

Peserta didik menjadikan madrasah sebagai status awal yang menunjukkan bahwa dia memiliki dasar pendidikan agama. Kepastian pernah mengikuti mata pelajaran diniyyah di Madrasah Tarbiyyatul Auladil Islam menjadi satu identitas penting bagi warga masyarakat Tambak Anyar Ulu. Identitas pernah mengenyam pendidikan madrasah, menjadi indikator kepribadian yang menjadi semacam jaminan kualitas individu. Atas dasar identitas dan indikator kepribadian seseorang itu, maka spirit religi peserta didik dalam meningkatkan partisipasi di bidang pendidikan Islam pada Madrasah Tarbiyyatul Auladil Islam Tambak Anyar Ulu justru menjadi motif yang penting untuk dipahami.

\section{Spirit Religi Pengelolaan Madrasah Tarbiyyatul Auladil Islam Tambak Anyar Ulu}

Niat ikhlas masyarakat Tambak Anyar Ulu untuk memiliki sebuah lembaga pendidikan swasta, telah nyata terealisir sejak tahun 1956. Sekarang telah semakin maju dengan fisik bangunan yang baik, sesuai usianya yang sudah mencapai 58 tahun. Artinya, lembaga pendidikan Islam dalam bentuk madrasah swasta yang bernama Tarbiyyatul Auladil Islam telah berhasil dikelola secara baik.

Masyarakat Tambak Anyar Ulu yang sangat religius secara gotong royong gawi sabumi telah mampu menunjukkan kekuatan swadaya murni sebagai ciri khasnya dalam membangun madrasah swasta Tarbiyyatul Auladil Islam. Artinya, sistem pengelolaan madrasah swasta itu telah sesuai dengan kultur masyarakat setempat. Sebuah kekuatan sosial budaya tidak akan bertahan lama jika tidak mendapat dukungan masyarakatnya.

Pembahasan ini menjadi menarik karena menyangkut konsep pengelolaan pendidikan yang memerlukan pembiayaan yang besar. Namun, Madrasah Tarbiyyatul Auladil Islam yang telah dikelola dengan baik, tentunya memiliki nilia-nilai terbaik yang menjadi etika manajemen, sehingga mampu berkembang seiring dengan kemauan masyarakat.

Etika manajemen madrasah swasta yang bertumbuh secara tradisi dalam masyarakat Indonesia, menunjukkan satu pola yang cenderung sama, tetapi hanya dari segi sistem strategi pengelolaan yang dipermukaan nampak berbeda. Oleh sebab itu, jawaban atas efektifnya pola 
manajemen itulah yang menjadi penting karena terkait langsung dengan spirit religi yang menjadi pokok kekuatan etika manajemen madrasah swasta.

Masyarakat Tambak Anyar Ulu, telah menyepakati untuk pengelolaan madrasah berdasarkan kesepakatan tokoh masyarakat desa, alim ulama, tokoh pemuda, dan warga masyarakat yang peduli atas kemajuan pendidikan Islam. Kesepakatan yang menghasilkan perlunya pembentukan panitia madrasah sebagai pengelola manajemen madrasah, sebagai kesepakatan kolektif atas azas musyawarah yang menjadi ciri masyarakat Tambak Anyar Ulu.

Panitia madrasah bertanggungjawab kepada komponen masyarakat desa yang terdiri dari; tokoh masyarakat yakni Pembakal, Ketua BMD (Badan Musyawarah Desa), Ketua-Ketua RT, Alima Ulama, guru-guru agama, tokoh-tokoh pemuda, warga desa yang peduli pendidikan Islam. Konsep panitia madrasah berdasarkan suatu semboyan, "panitia madrasah boleh silih berganti orangnya, namun madrasahnya selalu tegak sepanjang waktu”. Realitas ini tentunya mengharuskan perhatian kepada panitia madrasah, tentang motif keberhasilan pengelolaan madrasah sehingga tergambar spiritnya.

Kembali etika Islam memberi ruang atas kekuatan manajemen pada madrasah Tarbiyyatul Auladil Islam Tambak Anyar Ulu. Kekuatan manajemen itu dilandasi dilandasi semangat untuk mendapat berkah. Keberkahan adalah dambaan seorang muslim dalam hidupnya. Keberkahan adalah nilai tambah yang diperoleh seseorang dari rezeki yang didapatnya. Landasan utama mencapai keberkahan pada panitia madrasah adalah melaksanakan tanggungjawab dengan amanah. Amanah adalah salah satu dari sifat Rasulullah Saw. Amanah adalah kepercayaan, yang dalam konteks Panitia Madrasah Tarbiyyatul Auladil Islam Tambak Anyar Ulu sebagai orang-orang yang dipercaya masyarakat desa untuk mengurus madrasah agar keberlangsungan pendidikan Islam berjalan dengan baik.

Sifat amanah adalah sifat murni manusia. Hal ini disabdakan oleh Rasulullah Saw, yang artinya: "Sesungguhnya amanah itu turun dari hati manusia. Kemudian Al-Qur'an turun dan mereka pun mendapat pengetahuan dari Al-Qur'an dan Sunnah" (HR Tirmidzi).

Melalui sifat amanah, panitia madrasah merefleksikan kejujurannya dalam mengurus madrasah. Kejujuran dalam pengelolaan keuangan merupakan kunci kepercayaan masyarakat. Sifat jujur merupakan sifat yang mulia, yang melandasi sifat amanah.

Pengelolaan Madrasah Tarbiyyatul Auladil Islam Tambak Anyar Ulu yang didasarkan pola 'titipan amanah' masyarakat kepada panitia madrasah merupakan manajemen berbasis masyarakat. Masyarakat menghendaki pengelolaan madrasah secara komunal, gotong royong 
dan saling percaya. Realitas ini sesuai dengan pola masyarakat Tambak Anyar Ulu yang religius dan sifat masyarakat desa yang sabubuhan serta papadaan.

Manajemen berbasis masyarakat adalah manajemen kepercayaan. Semua upaya memajukan madrasah selalu diputuskan dalam musyawarah panitia madrasah yang dibawa ke tingkat musyawarah desa. Dalam musyawarah desa yang dihadiri unsur: Kepala Desa (Pembakal), Ketua BMD (Badan Musyawarah Desa), dan anggotanya, para Alim Ulama desa, para orang tua murid yang mewakili, ketua-ketua RT dan tokoh-tokoh pemuda desa.

Laporan keuangan madrasah selalu disampaikan dalam setiap rapat pada forum rapat musyawarah desa. Selama ini di dalam panitia Madrasah Tarbiyyatul Auladil Islam Tambak Anyar Ulu, belum pernah ada kecurangan penggunaan keuangan. Hal ini disebabkan semua anggaran madrasah telah ditentukan dalam setiap enam bulan dalam rapat forum musyawarah desa.

Secara transpran, disetiap acara saprah amal hasil semua kegiatan diumumkan di penghujung acara seusai tabligh akbar, sehingga semua masyarakat tahu hasil yang diperoleh. Selain itu, dalam tiap acara saprah amal, semua komponen terlibat dalam kegiatan mencari pemasukan keuangan madrasah. Komponen-komponen masyarakat itu, dapat menaksir sendiri hasil suatu kegiatan pencarian dana. Biasanya setiap satu minggu seusai acara saprah amal, kembali hasil sumbagan yang masuk ke kas madrasah dibacakan dan diumumkan oleh pengurus masjid Jami As-Sholihin Tambak Anyar Ulu menjelang sholat Jum'at.

Tidak ada dana yang dibayar untuk jerih payah panitia madrasah karena semua elemen terlibat dalam kegiatan saprah amal. Semua elemen masyarakat ikut berpartisipasi menyumbangkan pikiran, tenaga dan biaya dalam puncak acara peringatan Maulid Nabi Muhammad Saw serta peringatan Isra dan Mi'rajnya Nabi Muhammad Saw. Menjadi panitia Madrasah Tarbiyyatul Auladil Islam Tambak Anyar Ulu tidak mendapatkan honor, tidak ada dividen, tidak ada insentif. Semuanya; pikiran, tenaga, biaya, waktu diserahkan sepenuhnya demi kepentingan pendidikan Islam di desa tersebut. Berkahnya, diserahkan sepenuhnya kepada kemurahan Allah Swt, baik di dunia maupun di akhirat. Demi 'berkah' inilah yang menjadi spirit religi yang sangat kuat, meneguhkan pengelolaan tradisi madrasah dalam masyarakat desa Tambak Anyar Ulu.

Panitia madrasah pada dasarnya panitia yang menjalankan tugas sebagai penerima mandat masyarakat desa yang bertanggungjawab melaksanakan penggalangan dana amal. Dana amal juga bersumber dari masyarakat desa. Kemudian panitia madrasah mengelola 
keuangan madrasah baik untuk pembangunan fisik, seperti rehab fisik, pembelian meja kursi pembelajaran jika diperlukan dan bersama-sama Kepala Madrasah menentukan pengajar madrasah, serta mengelola keuangan madrasah, khususnya yang berkaitan dengan keperluan gaji guru. Kepala madrasah mengusulkan kepada panitia madrasah dalam bentuk usul keperluan alat tulis kantor yang dikelola bendahara madrasah.

Bentuk partisipasi pemerintah, dalam hal ini Kantor Departemen Agama Kabupaten Banjar memberikan bantuan bagi Madrasah Tarbiyyatul Auladil Islam Tambak Anyar Ulu. Sesuai dengan jenis madrasah, yakni madrasah diniyyah swasta, maka Departemen Agama Kabupaten Banjar tidak memberikan bantuan dalam bentuk apapun. Namun, sebelumnya pernah memberikan bantuan guru negeri satu orang sebelum tahun 1972. Kemudian sejak adanya dana BOS (Bantuan Operasional Sekolah) yakni tahun 2010-2011 untuk guru-guru madrasah sebesar Rp.500.000 perorang, Madrasah Tarbiyyatul Auladil Islam sempat menerima sekitar enam bulan, namun karena kekhilafan dalam tata kelola administrasi, maka Dewan Guru Madrasah ini meminta bantuan itu dihentikan, agar tidak membawa persoalan yang merugikan bagi madrasah.

\section{KESIMPULAN}

Bentuk-bentuk aktivitas spirit religi masyarakat Tambak Anyar Ulu dalam upaya meningkatkan partisipasi dibidang pendidikan madrasah swasta merupakan refleksi dari kehidupan sosial budaya masyarakat setempat yang telah memiliki dasar kehidupan religius Islami. Masyarakat religius Islami membangun pola partisipasi dibidang pendidikan madrasah swasta berdasarkan etika Islam yang bersumber dari Al Qur'an dan As Sunnah (Al Hadist). Etika Islam diaplikasikan masyarakat Tambak Anyar Ulu dengan spirit religi yang kuat, untuk membangun dan menyelenggarakan pendidikan Islam melalui madrasah Tarbiyyatul Auladil Islam. 


\section{DAFTAR PUSTAKA}

Abdullah, Taufik. 1979. Tesis Weber dan Islam di Indonesia, dalam Agama, Etos Kerja dan Perkembangan Ekonomi. Jakarta. LP3ES.

Alatas, Hussein. 1979. Tesis Weber dan Asia Tenggara, dalam Agama, Etos Kerja dan Perkembangan Ekonomi. Jakarta. LP3ES.

Al-Hasyimi, Abdul Mun'im. 2009. Akhlak Rasul Menurut Bukhari \& Muslim, Jakarta. Gema Insani.

Departemen Agama Republik Indonesia. 1965. Al Qur'an dan Terdjemahnja. Jakarta. Lembaga Penjelenggara Penterjemah Kitab Suci Al Qur'an.

Dhofier, Zamakhsyari. 2011. Tradisi Pesantren, Studi Pandangan Hidup Kiyai dan Visinya Mengenai Masa Depan Indonesia. Jakarta. LP3ES.

Durkheim, Emile. 2011. Penerjemah Inyiak Ridwan Muzir dkk. The Elementry Forms of The Relegious Life, Sejarah Bentuk-Bentuk Agama yang Paling Dasar. Jogjakarta. Ircisod.

Harrison E. Lawrence, Samuel P. Huntington. 2006. Kebangkitan Peran Budaya, Bagaimana Nilai-Nilai Membentuk Kemajuan Manusia. Jakarta. LP3ES.

Hasan, Moh. Syamsi. Tt. Hadis-Hadis Populer Shahih Bukhari \& Muslim. Surabaya. Amelia.

Hawari, Dadang. 2007. Dimensi Religi dalam Praktek Psikiatri dan Psikolog. Jakarta. FK. UI

Koentjaraningrat. 1986. Pengantar Ilmu Antropologi. Jakarta. Aksara Baru.

Koentjaraningrat. 2002. Manusia dan Kebudayaan di Indonesia. Jakarta. Djambatan.

Madjid, Nurcholish. 2008. Islam Agama Peradaban, Membangun Makna dan Relevansi Doktrin Islam dalam Sejarah. Jakarta. Paramadina-Dian Rakyat.

Muhaimin. 2006. Nuansa Baru Pendidikan Islam. Jakarta. Raja Grafindo Perkasa.

Putra, Nusa. 2013. Penelitian Kualitatif IPS (Ilmu Pengetahuan Sosial). Bandung, Remaja Rosda Karya.

Putro, Herry Porda. N. 1990. Laporan Pengabdian Pada Masyarakat Tentang Kesadaran Masyarakat Terhadap Peninggalan Sejarah Lokal-Banjar. Banjarmasin. Program Studi Pendidikan Sejarah FKIP UNLAM.

UU Sistem Pendidikan Nasional. UU RI No. 20 Tahun 2003. Jakarta, Sinar Grafika. 
Wahyu, 2012. Metodologi Penelitian Kualitatif. Banjarmasin. Universitas Lambung Mangkurat FKIP.

Weber, Max. 2012. Penerjemah Abdul Qadir Saleh dkk. Teori Analisis Kebudayaan. Jogjakarta. Ircisod.

Yusliani Noor. 2012. Sejarah Perkembangan Islam di Banjarmasin dan Peran Kesultanan Banjar (Abad XV-XIX). Makalah. Banjarmasin, Kesultanan Banjar Darussalam.

\section{Internet}

BPS Provinsi Kalimantan Selatan, http://kalsel.bps.go.id/

Jumlah Madrasah Ibtidaiyyah di Kalimantan Selatan. diakses 2 Januari 2014.

Huntington dalam Yudi Latif. Momentum Kebangkitan. www.republika.co.id diakses 23 April 2014.

Karl Marx, Sekularis me

http:/budieagung.wordpress.com/201/10/23-pemikiran-filsafat-sekularisme

diakses

September 2014. 